\title{
The Students' Attitude and Learning Experience toward Flipped Classroom Implementation During COVID-19 Outbreak: A Survey Study
}

\author{
Marta Betaubun \\ Department of English Education, Universitas Musamus, Indonesia \\ *Corresponding e-mail: marthabetaubun@unmus.ac.id
}

Received: 11 February 2021 Accepted: 03 March $2021 \quad$ Published: 22 March 2021

Abstract: The Students' Attitude and Learning Experience toward Flipped Classroom Implementation in ESP Class during COVID-19 Outbreak: A Survey Study. Objective: This study was to determine student attitudes and learning experiences related to the application of Flipped Classroom (FC) in English for Specific Purposes (ESP) classes during the COVID-19 pandemic. Method: A quantitative approach is used in this study by taking respondents from four classes of students in the engineering faculty at a university in Papua. Respondents of this study amounted to 200 who fill online questionnaire. The responses obtained were then analyzed using SPSS 23. Findings: Based on data analysis, students had a neutral attitude and have a reasonably good level of learning experience towards the application of FC. Conclusion: Application of FC strategies has benefits to be applied, especially in learning during the pandemic COVID-19.

Keywords: flipped classroom, student attitudes, learning experiences, digital learning, COVID-19.

Abstrak: Sikap dan Pengalaman Belajar Mahasiswa Terhadap Penerapan Flipped Classroom di Kelas ESP Selama Pandemi COVID-19: Penelitian Survey. Tujuan: Penelitian ini adalah untuk mengetahui sikap dan pengalaman belajar mahasiswa terkait penerapan Flipped Classroom (FC) pada kelas Bahasa Inggris untuk Tujuan Khusus (ESP) di masa pandemi COVID19. Metode: Pendekatan kuantitatif digunakan dalam penelitian ini dengan mengambil responden dari empat kelas mahasiswa di fakultas teknik pada salah satu universitas di Papua. Responden dari penelitian ini berjumlah 200 yang mengisi kuesioner secara online. Respon yang diperoleh kemudian dianalisis menggunakan SPSS 23. Temuan: Berdasarkan analisis data, mahasiswa memiliki sikap yang netral dan tingkat pengalaman belajar cukup baik terhadap penerapan FC. Kesimpulan: Penerapan penggunaan FC memiliki manfaat untuk diterapkan khususnya dalam pembelajaran selama pandemi COVID-19.

Kata kunci: flipped classroom, sikap mahasiswa, pengalaman belajar, pembelajaran digital, COVID-19.

\section{To cite this article:}

Betaubun, M. (2021). The Students' Attitude And Learning Experience Toward Flipped Classroom Implementation During COVID-19 Outbreak: A Survey Study. Jurnal Pendidikan Progresif, 11(1), 54-62. doi: 10.23960/jpp.v11.i1.202105. 


\section{INTRODUCTION}

The development of the use of information technology, especially during the COVID-19 crisis, has impacted the learning process. These changes also target EFL's English learning. The use of technology makes it easy for instructors to shift traditional learning, delivering a speech in front of the class to become active learning. A flipped classroom (FC) is a learning approach that facilitates students' transformation into active learners (Turan \& Akdag-Cimen, 2020). Traditional learning is that students sit and listen, making students passive recipients (Haghighi, Jafarigohar, Khoshsima, \& Vahdany, 2019), reversed through $\mathrm{FC}$ with the learning content given before the class takes place (Little, 2015).

The FC learning approach can encourage students to become independent learners. In general, FC reverses learning to be carried out outside the classroom where instruction and assignments are carried out during class hours (Adnan, 2017; Bergmann \& Sams, 2012; KarabulutIlgu, Jaramillo Cherrez, \& Jahren, 2018; Moffett, 2015). The use of FC has been widely used across scientific disciplines such as in the field of machinery (Karabulutllgu et al., 2018; Mason, Shuman, \& Cook, 2013); mathematics (Lo, Hew, \& Chen, 2017; McGivney-Burelle \& Xue, 2013), health education (Hew \& Lo, 2018), foreign language learning (Hung, 2015; Wang, An, \& Wright, 2018) which are reported to increase learning outcomes. Moreover, FC is proven to transform students into independent learners and change the learning model to be focused on students (Amiryousefi, 2019; Han, 2015).

Research on FC shows a significant growth in recent times. The results of previous studies focused mostly on the FC method (Chen, Lui, \& Martinelli, 2017; Karabulutllgu et al., 2018; Lo et al., 2017). The FC research also explores students' perceptions of FC (Gilboy, Heinerichs, \& Pazzaglia, 2015; Roach,
2014) and the interactions between students and instructors (Çakici \& Oflaz, 2012; Sun \& Wu, 2016). On the other hand, limited FC research was conducted on EFL, which focused on methods (Amiryousefi, 2019; Ekmekci, 2017; Mehring, 2016).

There is very little research on flipped classrooms in EFL, especially in Indonesia (Afrilyasanti, Cahyono, \& Astuti, 2017; Zainuddin, 2017; Zainuddin \& Perera, 2019). This study seeks to expand the scope of research subjects that have not been carried out in previous studies in Indonesia, especially in the 3T area. To date, their limitation in FC-related research has focused on learning in the $3 \mathrm{~T}$ area. Research on subjects located in the $3 \mathrm{~T}$ area is essential because the findings of this study will provide comprehensive information on the application of FC. This information can become a foundation for further action in the form of policies and changes in approaches related to learning strategies that are applied explicitly in $3 \mathrm{~T}$ areas or urban areas with a minimal teaching infrastructure.

This study will explore FC from the student's point of view related to attitudes and perspectives on the application of FC in a tertiary institution in the border area of Indonesia. Furthermore, this research will conduct a survey related to student attitudes and learning experiences obtained from the application of FC during the COVID-19 crisis. Meanwhile, the use ofFC can improve student achievement is still being debated (Haghighi et al., 2019; SteenUtheim \& Foldnes, 2018), and FC also received an assessment of both positive and negative perceptions from students (Findlay-Thompson $\&$ Mombourquette, 2014). The exploration of students' attitudes towards FC's application can provide a different picture of students' attitudes and experiences. This study's findings will provide a different perspective from previous studies regarding the application of FC in the 
3T area, which has different characteristics from previous studies.

The FC learning approach has its own characteristics that are contrary to traditional learning. FC has an approach where the tasks and learning behind are outside the classroom (Adnan, 2017; Chen Hsieh, Wu, \& Marek, 2017; KarabulutIlgu et al., 2018). Meanwhile, Chen et al. (2017) underlined the principles of FC based on the four pillars of F-L-I-P. A flexible environment allows students to get learning both outside the classroom and inside the classroom. Learning culture changes the traditional learning tradition where students become passive learners, or spoon-feeder learners are transformed into active learners who can access material online and apply it in the classroom. Intentional content allows the material to be arranged focused on a particular theme for student access. Professional educators require instructors to prepare materials, present them online, guide students in a class, and provide assessments or feedback online and in class.

Moreover, the presentation of information is usually presented via video so that students in the class can focus on being involved in activities and implementing concepts accompanied by the teacher (Chen Hsieh et al., 2017; Mehring, 2016). (Chen Hsieh, Wu, \& Marek, 2017; Mehring, 2016). FC is inseparable from technology, which aims to divert the presentation of material out of class (Haghighi et al., 2019). Primary activities in the form of delivering material are no longer carried out in class through FC, but students prepare and study material outside the classroom (Mehring, 2016). With FC, classroom activities allow instructors to discuss, provide real examples, stimulate students to think critically and guide learning activities (Mehring, 2016). In conclusion, FC aims to convert traditional learning in which educators usually carry out the delivery of material through lectures in the classroom into students actively learning outside the classroom using technology. Moreover, in-class activities are the actualization of student learning outcomes where educators become facilitators to create focused material that can be accessed by students online, ensure student understanding, guide students in carrying out class activities, and stimulate students to become independent learners who can think critically.

The use of technology supports the delivery of FC materials online. FC changes the delivery of material face-to-face into material conveyed in narrative form through various media (Moravec, Williams, Aguilar-Roca, \& O'Dowd, 2010). Instructors have two choices in using learning narratives for use by students either by recording them independently(McGivney-Burelle $\&$ Xue, 2013) or choosing to use available learning materials that can be taken from the website (Hung, 2015; Zainuddin \& Halili, 2016). The medium of delivery, which is quite popular in FC, is in the form of video. Videos can adjust students' time to study with video features in the form of replay or pause (Chen Hsieh et al., 2017; Zhonggen \& Guifang, 2016). However, the media for delivering material outside the classroom varies, which is not only specific to watching videos but can also be done by reading the book or listening to podcasts (Moffett, 2015).

The use of videos to deliver learning materials to FC is often seen as a priority. FC has a broader scope than just video usage (Bergmann \& Sams, 2012). By delivering material via video, $\mathrm{FC}$ also has other formats in pre-class assignments to support students to have better participation in class, which can be quizzes or worksheets (Hung, 2015). The essence of FC is not only in the form of students seeing videos of learning material outside the classroom but also in students' and instructors' involvement in active learning (Adnan, 2017).

FC has a positive rating to apply to the EFL context. FC can further explore the use of 
communication in English, which is carried out in the classroom (Bergmann \& Sams, 2012), which is carried out collaboratively between students and instructors (Mehring, 2016) so that better language skills can be achieved (Turan \& AkdagCimen, 2020). It can be realized that one of the basic elements in FC, namely learning in the classroom, has activities in individual feedback, discussions, and group activities (McLaughlin, White, Khanova, \& Yuriev, 2016). Moreover, the application of FC to the EFL context contributes to the formation of a communicative and student-focused learning environment (Mehring, 2016).

In general, FC provides benefits to be applied to learning. Statistically, students experience an increase in learning performance (Chen Hsieh et al., 2017; Hung, 2015). FC is successfully implemented because students are provided with sufficient learning material before they come to class to have increased competence in class (Haghighi et al., 2019). On the other hand, FC plays a role in empowering students to become independent learners (Little, 2015). Based on these results, FC can play an essential role in improving student performance.

\section{RESEARCH METHOD}

A quantitative approach was used in this study to explore student attitudes and learning experiences through the application of FC during the COVID-19 pandemic. This research was conducted at a university in Papua. Research samples were taken from students at the engineering faculty. Respondents came from students in the English for Specific Purpose (ESP) class who carried out learning activities during the COVID-19 pandemic. Classes are conducted using the FC method, where students are given material consisting of modules and video podcasts before lectures are conducted either online or face-to-face. The total number of respondents involved was 200 students spread over four different classes. Demographic data of respondents are shown in Table 1.

Table 1. Respondents Demographic Information

\begin{tabular}{lll} 
Variables & $\mathbf{N}$ & $\mathbf{\%}$ \\
\hline Gender & 95 & 47.40 \\
Male & 105 & 52.60 \\
Female & & \\
\hline Ethnicity & 169 & 84.60 \\
Non-Papua & 31 & 15.40 \\
Papua & 115 & 57.70 \\
\hline Owned Devices & 182 & 91 \\
Laptop & 8 & 3.80 \\
Smartphone & 10 & 5.10 \\
Tablet & & \\
Basic Phone &
\end{tabular}

The instrument used in this study was used to measure students' attitudes and learning experiences in implementing the FC method of learning. The instrument was adapted from previous research (Hung, 2015) and then translated into Indonesian to make it easier for respondents to answer the questionnaire. The instrument used a five-point Likert scale. Pilot testing was carried out on the questionnaire then tested the reliability and validity using SPSS 23 with the reliability test results at 0.73 and the validity at 0.44 , where the instrument was declared fit for use. Furthermore, the questionnaire is then filled out online using the google form. The class leader distributes the filling link via the WhatsApp group. The time for filling is done in the middle of the semester in October 2020 . 
The responses of the research subjects obtained were then analyzed by employing a quantitative analysis. Data from respondents in the form of attitudes and learning experiences were processed using descriptive statistics (mean) analysis to describe the pattern obtained based on the survey using SPSS 23 (Appendix A). The first analysis stage is describing e the respondents' attitude toward the implementation of FC. Then, the second stage of analysis is an analysis of student learning experiences using the application of the FC strategy. Furthermore, After the data were analyzed descriptively, the researcher interpreted the data and discussed the results. Researcher adapt the interpretation framework of attitudes (Kurniawan, Astalini, Darmaji, \& Melsayanti, 2019) with the framework of a negative attitude $(x[=1.0-1.6)$, a neutral attitude $(\mathrm{x} \square=1.7-3.4)$, and a positive attitude $(\mathrm{x} \square=3.5-5.0)$. Researcher also adapt the learning experience interpretation framework (Awidi \& Paynter, 2019) with the framework of dissatisfied $(\mathrm{x} \square=1.0-1.6)$, quite satisfied $(\mathrm{x} \square=$ 1.7-3.4), and satisfied $(x \square=3.5-5.0)$.

\section{RESULT AND DISCUSSION}

This study uses descriptive statistics (mean) analysis to analyze student attitudes and student experiences regarding the application of FC in the ESP class during the COVID-19 pandemic. The study's first objective was to explore students' attitudes towards applying FC in ESP classes. On average, students have a positive attitude towards the application of FC. There is a finding that students choose neutral answers related to the transformation of traditional learning models with student-centred learning $(\mathrm{x} \square=$ 3.33). Furthermore, students also chose neutral answers related to their attitudes towards discussion and presentation activities on $\mathrm{FC}(\mathrm{x} \square$ $=3.17$ ). On the other hand, students give a positive attitude $(\mathrm{x} \square=4.50)$ to student satisfaction in FC. Furthermore, students have a neutral attitude $(x \square=2.17)$ regarding the application of FC compared to conventional classes where students just sit quietly, and the lecturer explains.

In addition, students stated a neutral attitude $(\mathrm{x} \square=2.83)$ towards the possibility of FC giving pressure to students. Students also have a neutral attitude $(\mathrm{x} \square=2.83)$ regarding their interest in joining other classes that use FC. Regarding the attitude of students' ability to carry out learning with FC, students have a neutral attitude regarding their ability to find material in pdf form ( $\mathrm{x}(=2.83)$. The neutral attitude of this student is in line with the student's ability to use the material and run tests online $(x \square=2.67)$.

Furthermore, the final component related to student attitudes towards the application of FC shows that students, on average, have a positive attitude towards the application of digital media in FC learning. Students have a positive attitude regarding digital media use in carrying out learning $(\mathrm{x} \square=4.33$ ). This finding is in line with the positive attitude of students regarding the level of motivation in learning to use digital media $(x \square=$ 4.38). Another finding shows that students have a positive attitude regarding learning using digital media $(x \square=3.83)$.

Besides, this study aims to determine student learning experiences related to the application of FC. In general, students are quite satisfied with the application of FC during the COVID-19 pandemic, as in Table 2. Students think that the application of FC is not burdensome to understand the material $(\mathrm{x} \square=3.0)$. Furthermore, students believe that the application of FC does not always make students less able to understand the material $(\mathrm{x} \square=3.33)$. Students also feel quite satisfied $(x \square=3.17)$ regarding the application of FC, which encourages them to become independent learners who can be actively involved in discussions and presentations.

Based on data analysis, globally, the student's attitude is at a neutral level. There are 
interesting findings from the results of data analysis in the form of students having a positive attitude regarding student satisfaction with FC application. The application of FC in learning will encourage students to become active learners, and they will also be more involved in learning so that they get the motivation to get better learning outcomes (Haghighi et al., 2019). The application of the FC requires several factors to be fulfilled. Teachers and students play an essential role in the running of FC. Teachers must be able to design the stages and learning materials correctly. Students have the responsibility to study material outside the classroom, and if they fail to do this, then the application of FC will not work because educators cannot make students involved in class (Chen Hsieh et al., 2017).

Another interesting finding from students' attitudes towards the application of FC is that they have a positive attitude towards the use of digital-based learning media. Students feel comfortable using digital media for learning. Besides that, students also have the motivation to learn to use digital media. The findings of this study are in line with the findings of previous research related to digital media providing more motivation for students to take part in learning (Hess, 2014; Lin \& Chen, 2017; Safaruddin, Ibrahim, Juhaeni, Harmilawati, \& Qadrianti, 2020; Schneider, Nebel, Beege, \& Rey, 2018).

FC requires several qualifications to apply so that FC benefits can be obtained. With all the benefits contained in FC, this learning method is feasible to be applied by educators. FC has generally received positive ratings from students (Bishop \& Verleger). On the other hand, educators must provide feedback to students to find out their level of success through the reflection method (McLaughlin et al., 2016). The application of FC using digital learning media is interesting for students so that students have a positive attitude, especially in the aspects of motivation and comfort in learning.
In addition, the second objective of this study is to explore students' learning experiences gained from implementing FC. Another finding related to students' learning experiences on the application of FC shows that students are quite satisfied $(x \square=3.0)$ because they get the motivation to learn English independently. Furthermore, students also felt quite satisfied (x $\mathrm{x}$ $=2.83$ ) with the application of FC, which motivated them to pre-class and in-class activities. Students have an immensely satisfying response $(\mathrm{x} \square=3.17)$ regarding the comfort students get with the FC. Students are also quite satisfied in having the experience to carry out FCbased learning $(x \square=2.67)$.

Furthermore, this study evaluates students' perceptions of their experiences using online learning media that is implemented through FC. Students have an entirely satisfying response $(x \square$ $=2.67$ ) to applying online-based exam media used in the learning process. The use of online tests with google form on the application of FC received quite satisfied responses $(x \square=3.17)$ from students. The application of online learning using $\mathrm{FC}$ received a quite satisfying response $(\mathrm{x} \square$ $=3.0$ ) because they felt they could better understand the material. Besides that, students are quite satisfied $(\mathrm{x} \square=2.83)$ with online learning because students have an interest.

The last aspect related to student learning experiences related to the application of FC related to facilities has a quite satisfied response from students. Students are delighted $(\mathrm{x} \square=4.38)$ with the availability of digital material sources used in learning. The availability of digital material makes students feel quite satisfied $(\mathrm{x} \square=2.83)$ because it can support the learning process. Furthermore, students felt dissatisfied $(\mathrm{x} \square=1.15$ ) with the internet network used to access the material and carry out online tests.

In general, students' perceptions of their learning experiences are at a reasonably good level. The findings from data analysis are in line 
with previous research findings that state that FC can improve students' learning experience in the learning process if educators can actively invite students to discuss, provide challenging job descriptions, and actively monitor student activities in class (Mehring, 2016). Students are more satisfied with classes that implement FC (Davies, Dean, \& Ball, 2013), and FC gets appreciation from students for the quality of their learning (Findlay-Thompson \& Mombourquette, 2014). An interesting finding on the learning experience indicator is that students are satisfied with using material accessed digitally. This study's findings are directly proportional to students' positive attitudes toward using digital learning media. However, what is contradictory is the student's dissatisfaction with the facilities in the form of an internet network, making it difficult for them to access materials and online examinations.

Based on this study's findings, there are several implications for the field of education, especially at the higher education level. The limitations that come with the COVID-19 crisis require rapid adaptation by students, teaching staff, and universities where the application of FC can be applied plural because it has various benefits. In the application of FC, educators have a fundamental responsibility in the progress of the stages and the progress made by students so that the success of FC is very dependent on educators (Little, 2015). The university should be able to provide encouragement and support for teaching staff in implementing FC in learning.

\section{CONCLUSION}

This first research objective was to determine student attitudes towards the application of FC during the COVID-19 pandemic. Based on data analysis, on average, students showed a neutral attitude towards the application of FC. The second objective of this study is to determine students' learning experience in the application of FC. Further analysis showed that students were satisfied with the application of FC. The application of FC in the ESP class during the COVID-19 pandemic has benefited students. The university is suggested issuing a policy to encourage teaching staff to implement FC. One thing to highlight is the implementation of FC should be accompanied by infrastructure as well as an incentive for the teaching staff. FC can potentially be minimalizing face-to-face learning during the COVID-19 outbreak and encourage students to become independent learners. FC can be a solution for learning in higher education both during the COVID-19 and postpandemic times.

\section{- REFERENCES}

Adnan, M. (2017). Perceptions of senioryear ELT students for flipped classroom: A materials development course. Computer Assisted Language Learning, 30(3-4), 204-222.

Afrilyasanti, R., Cahyono, B. Y., \& Astuti, U. P. (2017). Indonesian EFL students' perceptions on the implementation of flipped classroom model. Journal of Language Teaching and Research, 8(3), 476-484.

Amiryousefi, M. (2019). The incorporation of flipped learning into conventional classes to enhance EFL learners' L2 speaking, L2 listening, and engagement. Innovation in Language Learning and Teaching, 13(2), 147-161.

Awidi, I. T., \& Paynter, M. (2019). The impact of a flipped classroom approach on student learning experience. Computers \& Education, 128, 269283.

Bergmann, J., \& Sams, A. (2012). Flip your classroom: Reach every student in every class every day: International society for technology in education. 
Bishop, J. L., \& Verleger, M. A. (2013). The flipped classroom: A survey of the research.

Çakici, D., \& Oflaz, A. (2012). Language Learning Strategies Used By Propective Teachers at English and German Language Teaching Departments. HONORARY CHAIRPERSON, 37.

Chen, F., Lui, A. M., \& Martinelli, S. M. (2017). A systematic review of the effectiveness of flipped classrooms in medical education. Medical education, 51(6), 585-597.

Chen Hsieh, J. S., Wu, W.-C. V., \& Marek, M. W. (2017). Using the flipped classroom to enhance EFL learning. Computer Assisted Language Learning, 30(1-2), 1-21.

Davies, R. S., Dean, D. L., \& Ball, N. (2013). Flipping the classroom and instructional technology integration in a college-level information systems spreadsheet course. Educational Technology Research and Development, 61(4), 563-580.

Ekmekci, E. (2017). The flipped writing classroom in Turkish EFL context: A comparative study on a new model. Turkish Online Journal of Distance Education, 18(2), 151-167.

Findlay-Thompson, S., \& Mombourquette, P. (2014). Evaluation of a flipped classroom in an undergraduate business course. Business Education \& Accreditation, 6(1), 63-71.

Gilboy, M. B., Heinerichs, S., \& Pazzaglia, G. (2015). Enhancing student engagement using the flipped classroom. Journal of nutrition education and behavior, 47(1), 109-114.

Haghighi, H., Jafarigohar, M., Khoshsima, H., \& Vahdany, F. (2019). Impact of flipped classroom on EFL learners' appropriate use of refusal: achievement, participation, perception. Computer Assisted Language Learning, 32(3), 261-293.

Han, Y. J. (2015). Successfully flipping the ESL classroom for learner autonomy. NYS Tesol journal, 2(1), 98-109.

Hess, S. A. (2014). Digital media and student learning: Impact of electronic books on motivation and achievement. New England Reading Association Journal, 49(2), 35 .

Hew, K. F., \& Lo, C. K. (2018). Flipped classroom improves student learning in health professions education: a metaanalysis. BMC medical education, $18(1), 38$.

Hung, H.-T. (2015). Flipping the classroom for English language learners to foster active learning. Computer Assisted Language Learning, 28(1), 81-96.

Karabulutllgu,A., Jaramillo Cherrez, N., \& Jahren, C. T. (2018). A systematic review of research on the flipped learning method in engineering education. British Journal of Educational Technology, 49(3), 398-411.

Kurniawan, D. A., Astalini, A., Darmaji, D., \& Melsayanti, R. (2019). Students'Attitude towards Natural Sciences. International Journal of Evaluation and Research in Education, 8(3), 455-460.

Lin, M.-H., \& Chen, H.-g. (2017). A study of the effects of digital learning on learning motivation and learning outcome. Eurasia Journal of Mathematics, Science and Technology Education, 13(7), 35533564.

Little, C. (2015). The flipped classroom in further education: literature review and case study. Research in post-compulsory education, 20(3), 265-279.

Lo, C. K., Hew, K. F., \& Chen, G. (2017). Toward a set of design principles for mathematics flipped classrooms: A synthesis of research in mathematics 
education. Educational Research Review, 22, 50-73.

Mason, G. S., Shuman, T. R., \& Cook, K. E. (2013). Comparing the effectiveness of an inverted classroom to a traditional classroom in an upper-division engineering course. IEEE transactions on education, 56(4), 430-435.

McGivney-Burelle, J., \& Xue, F. (2013). Flipping calculus. Primus, 23(5), 477-486.

McLaughlin, J. E., White, P. J., Khanova, J., \& Yuriev, E. (2016). Flipped classroom implementation: A case report of two higher education institutions in the United States and Australia. Computers in the Schools, 33(1), 24-37.

Mehring, J. (2016). Present research on the flipped classroom and potential tools for the EFL classroom. Computers in the Schools, 33(1), 1-10.

Moffett, J. (2015). Twelve tips for "flipping" the classroom. Medical teacher, 37(4), 331336.

Moravec, M., Williams, A., Aguilar-Roca, N., \& O'Dowd, D. K. (2010). Learn before lecture: A strategy that improves learning outcomes in a large introductory biology class. CBE-Life Sciences Education, 9(4), 473-481.

Roach, T. (2014). Student perceptions toward flipped learning: New methods to increase interaction and active learning in economics. International review of economics education, 17, 74-84.

Safaruddin, S., Ibrahim, N., Juhaeni, J., Harmilawati, H., \& Qadrianti, L. (2020). The Effect of Project-Based Learning Assisted by Electronic Media on Learning Motivation and Science Process Skills. Journal of Innovation in Educational and Cultural Research, 1(1), 22-29.

Schneider, S., Nebel, S., Beege, M., \& Rey, G. D. (2018). The autonomy-enhancing effects of choice on cognitive load, motivation and learning with digital media. Learning and Instruction, 58, 161-172.

Steen-Utheim, A. T., \& Foldnes, N. (2018). A qualitative investigation of student engagement in a flipped classroom. Teaching in Higher Education, 23(3), 307-324.

Sun, J. C.-Y., \& Wu, Y.-T. (2016). Analysis of learning achievement and teacher-student interactions in flipped and conventional classrooms. International Review of Research in Open and Distributed Learning, 17(1), 79-99.

Turan, Z., \& Akdag-Cimen, B. (2020). Flipped classroom in English language teaching: a systematic review. Computer Assisted Language Learning, 33(5-6), 590-606.

Wang, J., An, N., \& Wright, C. (2018). Enhancing beginner learners' oral proficiency in a flipped Chinese foreign language classroom. Computer Assisted Language Learning, 31(5-6), 490-521.

Zainuddin, Z. (2017). First-Year College Students' Experiences in the EFL Flipped Classroom: A Case Study in Indonesia. International Journal of Instruction, 10(1), 133-150.

Zainuddin, Z., \& Halili, S. H. (2016). Flipped classroom research and trends from different fields of study. International Review of Research in Open and Distributed Learning, 17(3), 313-340.

Zainuddin, Z., \& Perera, C. J. (2019). Exploring students' competence, autonomy and relatedness in the flipped classroom pedagogical model. Journal of Further and Higher Education, 43(1), 115-126.

Zhonggen, Y., \& Guifang, W. (2016). Academic achievements and satisfaction of the clicker-aided flipped business English writing class. Journal of educational technology \& society, 19(2), 298-312. 
